\title{
Література:
}

1. Гродзинський М.Д. Пізнання ландшафту: місце і простір: у 2 т. К., 2005. T.1. $431 \mathrm{c.}$

2. Денисик Г.І. Антропогенне ландшафтознавство : навч. посіб. Частина I. Глобальне антропогенне ландшафтознавство. Вінниця, 2012. $306 \mathrm{c}$.

3. Давиденко В.А., Білявський Г.О., Арсенюк С.Ю. Ландшафтна екологія : навч. посіб. К., 2007. 280 с.

4. Кириченко С.А., Климчик О.М. Ландшафтно-екологічна оптимізація антропогенно змінених територій. Сучасні проблеми збалансованого природокористування : зб. матеріалів доп. учасн. IV наук.-практ. конф., листоп. 2009. Кам'янець-Подільський : ПДАТУ, 2009. C. 204-207.

5. Шищенко П.Г. Принципы и методы ландшафтного анализа в региональном проэктировании : монография. К., 1999. 284 с.

DOI https://doi.org/10.30525/978-9934-26-183-1-22

\section{ХАРАКТЕР МАСОВОГО РОЗПОВСЮДЖЕННЯ ВІДКЛАДЕНЬ ОЖЕЛЕДІ НА ТЕРИТОРІЇ УКРАЇНИ В ОСТАННС ДВАДЦЯТИРІЧЧЯ ПРОТЯГОМ 2001-2010 ТА 2011-2020 РР.}

\author{
Пясецька С. I. \\ кандидат географічних наук, \\ Украӥнський гідрометеорологічний інститут \\ Державної служби Украӥни з надзвичайних ситуачій \\ та Національної академії наук Украӥни \\ м. Київ, Украӥна
}

Відкладення ожеледі на території України протягом місяців холодного періоду року є типовим явищем. Такі відкладення відносять до несприятливих погодних явищ, а у ряді випадків за досягнення ними значних діаметрів до небезпечних та стихійних. До найбільш вагомих досліджень ожеледо-паморозевих явищ на території України, зокрема i відкладень ожеледі можна віднести ряд монографій які було видано співробітниками УкрГМІ протягом від другої половини 70-х та до початку 2000-х років [1-5]. Проте ряд питань щодо особливостей розповсюдження ожеледо-паморозевих відкладень та їх сучасного стану 82 
не було вирішено, зокрема їх масовий характер прояву по території України. Особливо несприятливими $є$ випадки відкладень ожеледі масового характеру розповсюдження.

За випадок масового розповсюдження відкладень ожеледі приймалась дата коли такі відкладення спостерігались не менш ніж на 10 станціях та не менш ніж у 2-х областях одночасно за спостереженнями на стандартному ожеледному станку.

Період 2001-2010 рр. Було встановлено, що у першому 3 досліджуваних десятиріч (2001-2010рр.) загальна кількість таких випадків становила 213. По окремих місяцях досліджуваного періоду було встановлено, що найбільша кількість таких випадків спостерігалась у січні, лютому та грудні, що відповідно становило 25,8, 26,3 та 31,0 \% від загальної кількості. У березні та листопаді їх повторюваність становила відповідно 7,5 та 9,4 \% від загалу. По окремих роках десятиріччя найбільша кількість таких випадків спостерігалась у січні 2003 р. 12 випадків (21,8 \%), 2004 р. - 7 (12,7\%), 2010 - (16,4 \%); лютому 2001 p. - 10, 2003 р. - 14, 2006 р. - та 2010 р - 12, відповідно 17,8; 14,3; 16,1 та 21,4\%, березні -2008 р. - 8 випадків (50,0\%), листопаді 2005 р 8 (40,0 \%), грудні 2007 р. - 10, 2009 р. - 7 та 2010 р - 12, відповідно 15,2; 10,6 та 18,2 \%. Протягом квітня та жовтня цього періоду випадків масового розповсюдження ожеледі не спостерігалось. Загалом по роках періоду найбільша кількість випадків масового розповсюдження відкладень ожеледі спостерігалась у 2003 р. - 31 випадок (14,3 \%), 2006 - 29 (13,6 \%), 2010 - 34 (16,0 \%). На решту років припало від 6,1 до 9,9 \% випадків, причому щонайменше на 2008 р. (6,1%) та 2009 р. $(6,6 \%)$.

Встановлено, що у більшості досліджуваних місяців найбільша кількість станцій у випадках масового розповсюдження ожеледі припадала на 3 градації - 11-15; 16-20 та 21-25 станцій. Причому більш переважали градації 11-15 станцій у січні, лютому та березні (25,0 $39,3 \%)$, у листопаді градація 16-20 станцій (45,0 \%), а грудні градації 11-15 та 16-20 станцій (по 25,8 \% відповідно). Виявлено, що у березні на градацію 31-35 станцій припало 37,5 \% випадків. У січні, лютому та грудні спостерігаються випадки, коли кількість станцій під час масового розповсюдження відкладень ожеледі $\epsilon$ значною i становить від 36-40 станцій $\mathrm{i} \geq 41$, що становить відповідно 4,2 та 9,9 \%.У цілому за досліджувані місяці на градації кількості станцій 11-15; 16-20 та 21-25 припало 65,4\% або відповідно $11-15$-67 (31,5\%); 16-20 $45(21,2 \%) ; 21-25-27(12,7 \%)$. 
3'ясовано, що здебільшого протягом досліджуваних місяців такі відкладення одночасно спостерігались на території від 5-6 до 9-10 областей, дещо рідше 11-12. Особливо це стосується січня, лютого та грудня. Їх повторюваність, в залежності від місяця становила щонайменше від 10,0 \% у листопаді (градація 5-6 областей) до 31,3 \% у березні (градація 7-8 станцій). У решті місяців на ці градації припадало $15,2-30,0 \%$. На градації від 11-12 до $\geq 15$ припало менше випадків, особливо на градації 13-14 та $\geq 15$ областей. На градацію 11-12 областей припало щонайменше $12,5 \%$ у березні, а щонайбільше 18,2 \% у грудні. Повторюваність останніх 2-х становила щонайменше 6,3\% для градації 13-14 областей (березень), а щонайбільше 18,2 \% (січень). Для градації $\geq 15$ областей найменша повторюваність становила 5,0 \% у листопаді до $10,9 \%$ у січні. Повторюваність градацій 2 та 3-4 станції була найменшою і становила 1,5 \% у грудні та 10,0 \% у листопаді. Загалом протягом досліджуваних місяців періоду 2001-2010 pр. найбільша кількість випадків масового розповсюдження ожеледі припала на градацію 7-8 областей, повторюваність якої склала 25,8 \%. На градації 4-6 та 9-10 областей припало по 38 та 36 випадків відповідно, або 17,8 та 16,9\%. Загалом на градації від 5-6 до 9-10 областей припало 60,5 \% випадків. Найменша повторюваність становила 0,5 \% у градації 2 області та 8,9 \% у градації $\geq 15$ областей.

Період 2011-2020 pр. У десятиріччі 2011-2020 рр. збільшилась кількість випадків масового розповсюдження відкладень ожеледі на території України. Загальна кількість таких випадків становила 303, що на 90 випадків більше ніж у попередньому десятиріччі. Встановлено, що найбільший внесок у загальну кількість мали січень, листопад та грудень відповідно 33,7; 12,5 та 31,7 \%. При цьому треба зазначити, що у цілому порівняно із попереднім десятиріччям збільшилась кількість таких випадків у січні, березні, листопаді та грудні. Так, у січні зростання склало майже половину від минулого десятиріччя, а у грудні на третину. Збільшення кількості таких випадків у березні та листопаді також відбулось, проте менш суттєве, відповідно на 8 та 18 випадків. У лютому кількість випадків масового відкладення ожеледі навпаки зменшилась 3 56 випадків у 2001-2010 pр. до 45 у 2011-2020 pр. Крім того у жовтні зазначеного періоду спостерігався 1 випадок масового розповсюдження відкладень ожеледі, чого не спостерігалось у минулому десятиріччі. У квітні так само як і у 201-2010 рр. випадків масового розповсюдження відкладень ожеледі не спостерігалось. По окремих роках досліджуваного періоду встановлено, що найбільша кількість таких випадків спостерігалась у січні у 2011, 2015 pр. 15 випадків (по 14,7 \% у кожному) 
а також у 2013, 214 рр. - 12 випадків (по 11,8 \%) та 2017 р. - 11 випадків (10,8 \%). У лютому найбільша кількість таких випадків спостерігалась у 2014 р. - 12 випадків (26,7\%) та у2018 р. - 8 (17,8 \%). Протягом березня 2011-2020 pр. найбільша кількість випадків масового розповсюдження випадків відкладень ожеледі спостерігалась у 2013 та 2018 рр. - по 9 випадків у кожному з цих років (42,9\%). У жовтні періоду 2011-2020 pр. спостерігався лише 1 випадок таких відкладень у 2014 р. У листопаді найбільша кількість випадків масового розповсюдження відкладень ожеледі спостерігалась у 2014 та 2018 рp. і становила 7 випадків $(18,4 \%)$, а у грудні найбільша кількість таких випадків спостерігалась у 2020 р. - 19 випадків (19,8 \%), а також у 2014 р. - 16 (16,7 \%), 2018 р. - 15 (15,6 \%). У цілому протягом досліджуваного періоду найбільший внесок у загальну кількість випадків відкладень ожеледі мали 2014 р. - 48 випадків (15,8 \%), 2018 р. - 45 випадків (14,9 \%), а також 2013 р. - 36 випадків (11,9\%). У решті років внесок складав від 7,3 до 10,6 \%. Найменший внесок мав 2012 р. коли спостерігалось лише 12 випадків масового розповсюдження відкладень ожеледі територією України.

Встановлено, що так само як і у передньому десятиріччі кількість станцій у випадках масового розповсюдження відкладень ожеледі припадає на 3 градації кількості станцій: 11-15; 16-20 та 21-25. Особливо це помітно у січні, лютому, листопаді та грудні. Повторюваність для градації 11-15 станцій знаходиться у межах $27,1-31,4$ \% в залежності від місяця. В градації 16-20 станцій повторюваність становить 18,8 26,7 \%, а у градації 21-25 станцій відповідно 4,8 - 20,8 \%. Також збільшилась кількість випадків, коли кількість станцій, які в одну дату спостерігали відкладення ожеледі в градаціях 26-30 та 31-35 особливо у січні та грудні. На відміну від попереднього десятиріччя збільшилась кількість випадків із масовим розповсюдженням випадків відкладень ожеледі із кількістю станцій в градаціях 36-40 та $\geq 41$ станції. У першу чергу це стосується січня та грудня, проте зменшення у лютому. Встановлено, що у цілому на градації кількості станцій від 11-15 до 21-25 припало 60,0 \% випадків масового розповсюдження відкладень ожеледі.

Дослідження кількості областей показало, що так само як i y минулому десятиріччі основна маса таких випадків постерігається на території від 5-6 областей до 9-10. Однак, у різних 3 досліджуваних місяців пік повторюваності може дещо відрізнятись. Так ,наприклад у січні, березні, листопаді та грудні найбільша повторюваність припала на градацію 7-8 областей (відповідно 24,5; 23,8; 26,3; 27,1%), а у лютому 
на градацію 9-10 (33,3 \%). У січні помічено досить значна повторюваність в градаціях 11-12 та 13-14 станцій (відповідно 14,7 та 12,7 \%). У лютому також спостерігається збільшення кількості таких випадків у градації 13-14 областей. У листопаді збільшується повторюваність в градації 11-12 областей (21,1%). Найбільша повторюваність у градації $\geq 15$ областей спостерігається у листопаді та грудні, відповідно 10,5 та 11,5 \%. У поточному десятиріччі дещо збільшилась кількість випадків масового розповсюдження відкладень ожеледі та території 15 та більше областей. Також треба зауважити, що на відміну від попереднього десятиріччя збільшилась повторюваність випадків масового розповсюдження відкладень ожеледі на території 3-4 станції, особливо у лютому та березні. Загалом на градації від 5-6 областей до 9-11 припало 64,0 \% усіх випадків масового розповсюдження відкладень ожеледі.

Отже, протягом 2001-2010 pp. та 2011-2020 рр. на Україні випадки масових відкладень ожеледі найчастіше спостерігались у січні, лютому та грудні. Протягом 2011-2020 pр. загальна кількість випадків масового розповсюдження відкладень ожеледі істотно збільшилась, особливо у січні та грудні.

\section{Література:}

1. Климат Украины / Под ред. Г.Ф. Прихотько, А.В. Ткаченко, В.Н. Бабиченко. Л.: Гидрометеоиздат, 1967. 413 с.

2. Природа Украинской ССР. Климат / Под ред. К.Т. Логвинова, М.И. Щербаня. К.: Наукова думка, 1984. 231 с.

3. Стихийные метеорологические явления на Украине и Молдавии / Под ред. В.Н. Бабиченко. Л.: Гидрометеоиздат, 1991. 223 с.

4. Клімат України / За ред. В.М. Ліпінського, В.А. Дячука, В.М. Бабіченко. К.: Вид-во. Раєвського, 2003. 343 с.

5. Стихійні метеорологічні явища на території України за останне двадцятиріччя (1986-2005рр.) / За ред. В.М.Ліпінського, В.І.Осадчого, В.М. Бабіченко. К.: Вид-во Ніка-Центр, 2006. 311 с. 